\begin{tabular}{l|l|} 
JOURNAI OF SURIMI \\
(SUSTAINABLE RESEARCH IN MANAGEMENT OF AGROINDUSTRI) \\
$\begin{array}{l}\text { Homepage : } \text { https://ejournal.pnc.ac.id/index.php/surimi/index } \\
\text { e-ISSN 2776-7280 dan p-ISSN 2776-7272 }\end{array}$ \\
\hline
\end{tabular}

\title{
Pemanfaatan Kulit Jeruk Nipis (Citrus aurantifolia) Menjadi Handsanitizer Gel
}

\section{[Utilization of Lime Peel (Citrus aurantifolia) as Hand Sanitizer Gel]}

\author{
Nur Mu'min ${ }^{*}$, Mirnawati $^{2}$, Muhammad Yunus ${ }^{3}$ \\ 1,2 Dosen Program Studi Kimia, Fakultas Teknik, Universitas Teknologi Sulawesi \\ Jl. Talasalapang No. 51, Makassar, Indonesia \\ ${ }^{3}$ Dosen Program Studi Fisika, Universitas Negeri Gorontalo \\ Jl. Jenderal Sudirman No.6 Kota Gorontalo \\ Email korespondensi : muhsakhizaidan@gmail.com
}

\begin{abstract}
Hand sanitizer is a hand sanitizer antiseptic that is able to clean germs or viruses that stick to the hands. Most in the hand sanitizer market still use alcohol with a concentration of $\pm 50 \%-70 \%$. The use of alcohol in hand sanitizer is considered less safe for health because alcohol is an organic solvent that can dissolve the layer of fat and sebum on the skin that serves as a protector against infection of microorganisms. In addition, alcohol is also flammable and if repeated use on the hands will cause irritation. Research methods conducted in the determination of water content, the manufacture of hand sanitizer gel, $\mathrm{pH}$ measurement, viscosity and antimicrobials. Variations in carbpol concentration affect the physical properties and physical stability of the gel. Increased concentration of Carbpol increases the viscosity of the preparation. Based on the results of research conducted, it can be concluded that lime (Citrus aurantifolia) has the potential to inhibit the growth of microbes $<1,0 \times 10^{1}$ colonies $/ \mathrm{g}$.

Keywords: hand sanitizer, lime, Citrus aurantifolia, viscosity

\section{ABSTRAK}

Hand sanitizer merupakan antiseptik pembersih tangan yang mampu membersihkan kuman atau virus yang menempel pada tangan. Kebanyakan di pasaran hand sanitizer masih menggunakan alkohol dengan konsentrasi $\pm 50 \%-70 \%$. Penggunaan alkohol dalam pembersih tangan dirasa kurang aman terhadap kesehatan karena alkohol merupakan pelarut organik yang dapat melarutkan lapisan lemak dan sebum pada kulit yang berfungsi sebagai pelindung terhadap infeksi mikroorganisme. Selain itu, alkohol juga mudah terbakar dan apabila pemakaian berulang pada tangan akan menyebabkan iritasi. Metode penelitian yang dilakukan penetapan kadar air, pembuatan hand sanitizer gel, pengukuran $\mathrm{pH}$, viskositas dan antimikroba. Variasi konsentrasi karbopol mempengaruhi sifat fisik dan stabilitas fisik gel. Peningkatan konsentrasi Karbopol meningkatkan viskositas sediaan. Berdasarkan hasil penelitian yang dilakukan, maka dapat disimpulkan bahwa jeruk nipis (Citrus aurantifolia) memiliki potensi untuk menghambat pertumbuhan mikroba kapang sebesar $<1,0 \times 10^{1}$ koloni/g.

Kata kunci: hand sanitizer, jeruk nipis, Citrus aurantifolia, viskositas
\end{abstract}

\section{Pendahuluan}

Merebaknya wabah virus Covid-19 diberbagai negara termasuk Indonesia membuat seluruh masyarakat gelisah dan panik serta ekstra waspada sehingga orang berlomba-lomba untuk mengantisipasi keadaan ini, berbagai cara dilakukan untuk mencegah penularan virus ini, menyerbu apotek dan klinik kesehatan untuk membeli masker ataupun hand sanitizer (Suparsa et al., 2020).

Hand sanitizer merupakan antiseptik pembersih tangan yang mampu membersihkan kuman atau virus yang menempel pada tangan. Kebanyakan di pasaran hand sanitizer masih menggunakan alkohol dengan konsentrasi $\pm 50-70 \%$. Penggunaan alkohol dalam pembersih tangan dirasa kurang aman terhadap 
kesehatan karena alkohol merupakan pelarut organik yang dapat melarutkan lapisan lemak dan sebum pada kulit yang berfungsi sebagai pelindung terhadap infeksi mikroorganisme. Selain itu, alkohol juga mudah terbakar dan apabila pemakaian berulang pada tangan akan menyebabkan iritasi.

Meningkatnya keinginan masyarakat untuk menggunakan bahan alam atau "back to nature", ditanggapi dengan banyaknya produk-produk topikal berbahan aktif tanaman untuk perawatan kesehatan, kosmetik dan pencegahan penyakit. Hand sanitizer yang berasal dari bahan alam lebih aman digunakan, tidak mengandung zat kimia berbahaya, tidak merusak pernafasan dan aman untuk anak-anak (Sari \& Isadiartuti, 2006).

Beberapa bahan alam yang telah terbukti berkhasiat bagi manusia dan memiliki kandungan antiseptik adalah jeruk nipis (Citrus aurantifolia). Jeruk nipis dilaporkan mengandung senyawa metabolik sekunder seperti flavonoid, alkaloid, dan saponin. Saponin mempunyai kemampuan sebagai pembersih sehingga efektif untuk menyembuhkan luka terbuka, sedangkan tanin dapat digunakan sebagai pencegahan terhadap infeksi luka karena mempunyai daya antiseptik dan obat luka bakar. Flavonoid dan polifenol mempunyai aktivitas sebagai antiseptik. Kandungan dalam jeruk nipis ini flavonoid berfungsi sebagai antibakteri, antioksidan dan dapat menghambat pendarahan pada kulit (Suparsa et al., 2020).

Pada kulit jeruk nipis mengandung beberapa senyawa yang dapat dimanfaatkan lebih lanjut, seperti kandungan minyak atsiri di dalamnya. Minyak atsiri dalam kulit jeruk memiliki kandungan yang dapat di gunakan sebagai antiseptik. Metode ekstraksi digunakan untuk memperoleh ekstrak minyak atsiri dari kulit jeruk nipis. Salah satu metode ekstraksi adalah metode sonikator, metode ini digunakan untuk memperoleh hasil ekstrak yang maksimal tanpa menggunakan waktu yang lama. Tujuan dari penelitian ini adalah untuk mengetahui pembuatan hand sanitizer dengan memanfaatkan jeruk nipis (Citrus aurantifolia) yang berfungsi sebagai antiseptik mencegah penularan virus Covid-19.

\section{Metode Penelitian}

Alat adalah seperangkat alat $\mathrm{pH}$ meter, spektrofotometer UV, viskometer Brookfield, alat-alat gelas, autoclave, inkubator, blank disc, laminar airflow, moisture balance dan botol. Bahan utama penelitian adalah sampel kulit jeruk nipis (Citrus aurantifolia), karbopol 0,5\%, aquadest, TEA dan media GNA. Penetapan kadar air jeruk nipis (Citrus aurantifolia)

Penetapan kadar air sampel kulit jeruk nipis dilakukan dengan menggunakan alat Mouisture Balance selama 30 menit untuk sekali perlakuan, kemudian ditunggu sampai bobot konstan dan dilihat hasil kadar air dalam satuan persen b/b (\%). Kadar air adalah kandungan air yang ada di dalam sampel kulit jeruk nipis. Penentuan kadar air pada bahan dianggap penting untuk menentukan kualitas umur simpan suatu produk. Parameter susut pengeringan adalah pengukuran sisa simplisia setelah dilakukan pengeringan pada suhu $105{ }^{\circ} \mathrm{C}$ selama 30 menit atau sampai berat konstan yang dinyatakan sebagai nilai persen. Semakin banyak jumlah kulit jeruk nipis yang digunakan maka semakin tinggi kadar air yang dihasilkan.

Pembuatan hand sanitizer gel dari ekstrak kulit jeruk nipis

Pembuatan hand santizer dari kulit jeruk nipis pertama menyediakan sediaan gel dengan penambahan karbopol 0,5\% dengan air suling dalam gelas kimia. trietanolamin (TEA) dicampurkan ke dalam gel jeruk nipis (Citrus aurantifolia) lalu dihomogenkan. Ditambahkan ekstrak jeruk nipis (Citrus aurantifolia) 1:3. Dikemas ke dalam botol. Pembuatan karbopol 0,5\% yang diawali dengan mendispersikan karbopol ke dalam air sampai larutan koloid yang bersifat asam dengan viskositas rendah dan akan membentuk gel dalam viskositas tinggi. Pada penelitian ini, pembuatan basis gel dilakukan dengan mendispersikan karbopol dalam air kemudian diaduk cepat untuk mencegah terjadinya aglomerat, kemudian dinetralkan dengan pembuatan TEA (trietanolamin) sebagai basa. TEA yang digunakan pada formulasi gel hand sanitizer sebanyak dua tetes karena jika terlalu banyak maka akan terbentuk gel yang sangat kental (Wijaya, 2013).

Pengukuran $\mathrm{pH}$ gel hand sanitizer

Pengukuran $\mathrm{pH}$ dilakukan dengan mencelupkan $\mathrm{pH}$ meter kedalam sediaan gel yang telah dibuat kemudian mencatat nilai $\mathrm{pH}$ nya. 
Pengukuran viskositas hand sanitizer gel

Pengukuran viskositas dilakukan terhadap sediaan gel dengan menggunakan viskometer Brookfield dengan spindel no. 6 dan no. 7. Hal ini dilakukan dengan cara mencelupkan spindel ke dalam sediaan gel kemudian dilihat viskositasnya.

Pengujian Antimikroba Kapang

Menyiapkan LB $90 \mathrm{ml}$ dalam erlemeyer, menimbang sampel 10 gram dan dimasukkan sampel kedalam LB $90 \mathrm{ml}$ dan dihomogenkan, membuat 2 media masing- masing berisi $9 \mathrm{ml}$ LB didalam tabung reaksi untuk pengenceran $10^{-2}$ dan $10^{-3}$, inkubasi selama $3 \times 24$ jam.

\section{Hasil dan Pembahasan}

\section{Uji Kadar air}

Kadar air adalah kandungan air yang ada di dalam sampel kulit jeruk nipis. Penentuan kadar air pada bahan dianggap penting untuk menentukan kualitas umur simpan suatu produk. Parameter susut pengeringan adalah pengukuran sisa simplisia setelah dilakukan pengeringan pada suhu $105{ }^{\circ} \mathrm{C}$ selama 30 menit atau sampai berat konstan yang dinyatakan sebagai nilai persen. Semakin banyak jumlah jeruk nipis yang digunakan maka semakin tinggi kadar air yang dihasilkan, kadar air hand sinitizer menurut SNI maksimal $20 \%$.

Berdasarkan hasil penelitian yang dilakukan diperoleh nilai kadar air pada sampel kulit jeruk nipis berturut-turut 13,9\% dan 13,4\%. Berdasarkan SNI 02-3547-2008 kadar air maksimal adalah 20\%, dengan demikian kadar air kering kulit jeruk nipis memenuhi syarat SNI.

Pembuatan Handsanitizer gel dari ekstrak kulit jeruk nipis

Formula yang dirancang pada penelitian ini adalah hand sanitizer berbentuk gel dengan penambahan Karbopol 0,5\%. Pembuatan karbopol 0,5\% yang diawali dengan mendispersikan karbopol ke dalam air sampai larutan koloid yang bersifat asam dengan viskositas rendah dan akan membentuk gel dalam viskositas tinggi. Pada penelitian ini, pembuatan basis gel dilakukan dengan mendispersikan karbopol dalam air kemudian diaduk cepat untuk mencegah terjadinya aglomerat, kemudian dinetralkan dengan pembuatan TEA (trietanolamin) sebagai basa. TEA yang digunakan pada formulasi gel hand sanitizer sebanyak dua tetes karena jika terlalu banyak maka akan terbentuk gel yang sangat kental (Wijaya, 2013).

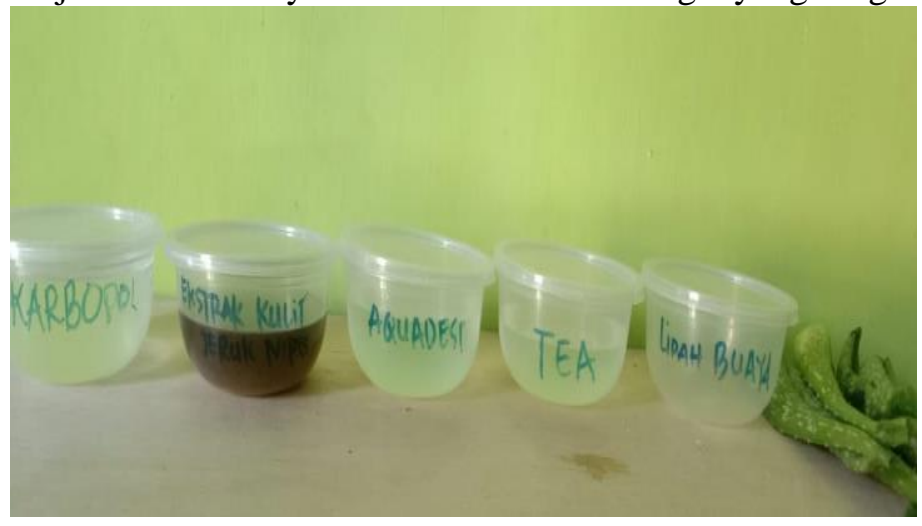

Gambar 1. Pembuatan handsanitizer

\section{Pengukuran $\mathrm{pH}$ Hand sanitizer}

Pemeriksaan $\mathrm{pH}$ merupakan salah satu dari uji secara kimia dalam menentukan kestabilan sediaan gel selama penyimpanan. Kestabilan $\mathrm{pH}$ selama penyimpanan harus diperhatikan. Nilai pH sediaan yang dapat diterima oleh kulit yakni antara 6-8 (Kuncari et al., 2014). Pengujian pH dilakukan untuk mengetahui stabilitas $\mathrm{pH}$ tiap formula gel yang dibuat sesuai atau tidak dengan $\mathrm{pH}$ kulit, karena apabila tidak sesuai dengan $\mathrm{pH}$ kulit maka akan mengakibatkan iritasi apabila terlalu asam, dan dapat mengakibatkan kulit bersisik bila terlalu basa. Berdasarkan hasil penelitian diperoleh nilai $\mathrm{pH}$ sebesar 7, dengan demikian nilai $\mathrm{pH}$ hand sanitizer dari jeruk nipis belum melampaui ambang batas $\mathrm{pH}$ pada kulit manusia. Nilai $\mathrm{pH}$ sediaan yang dapat diterima oleh kulit yakni antara 6-8 (Kuncari et al., 2014). 


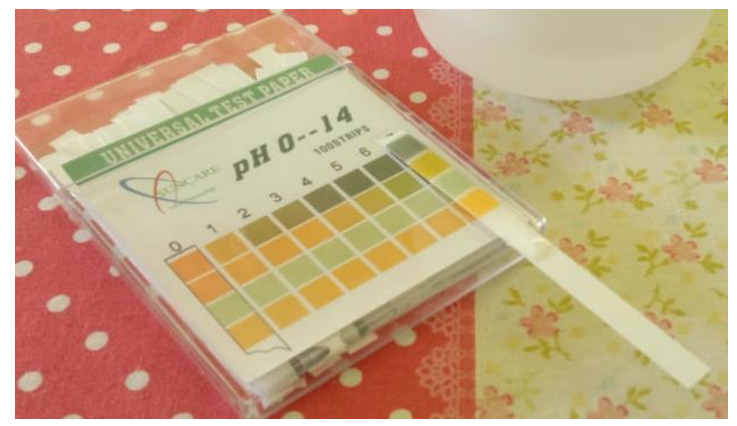

Gambar 2. Uji pH hand sanitizer pada jeruk nipis

\section{Pengukuran viskositas hand sanitizer gel}

Daya melekat suatu sediaan berbanding lurus dengan viskositas. Semakin tinggi viskositas suatu sediaan maka data melekatnya juga semakin tinggi. Daya lekat yang terlalu kuat akan menghalangi poripori kulit dan apabila terlalu lemah maka efek tidak akan tercapai (Hapsari et al. 2014). Peningkatan daya lekat juga dipengaruhi oleh viskositas gel yang meningkat pada variasi konsentrasi karbopol. Semakin lama gel melekat pada kulit menyebabkan gel semakin efektif karena absorbsi zat aktifnya meningkat. Berdasarkan hasil penelitian yang dilakukan diperoleh data tertera pada Tabel 1 memiliki nilai viskositas berbeda-beda. Semakin besar nilai konversi hand sanitizer jeruk nipis maka nilai viskositas yang dihasilkan juga semakin besar.

Tabel 1. Hasil pengukuran viskositas Hand sanitizer jeruk nipis

\begin{tabular}{|c|c|c|c|c|}
\hline RPM & Reading & Konv & Viskositas & $\begin{array}{c}\text { Kekentalan } \\
(\mathbf{c P})\end{array}$ \\
\hline 30 & 20,5 & 40 & 820 & \multirow{2}{*}{645,0} \\
\hline 60 & 23,5 & 80 & 470 & \\
\hline
\end{tabular}

Uji aktivitas antimikroba

Uji aktivitas antimikroba dari ekstrak kulit jeruk nipis bertujuan untuk mengetahui kemampuan senyawa metabolit sekunder yang terkandung pada kulit jeruk nipis untuk membunuh mikroba. Pada penelitian ini ekstrak jeruk nipis dilakukan kontak uji menggunakan tiga jenis mikroba yaitu Bacillus cereus, kapang, dan Escherichia coli. Berdasarkan hasil penelitian diperoleh hasil yang tertera pada Tabel 2.

Tabel 2. Perhitungan bakteri

\begin{tabular}{lll}
\hline Parameter & Satuan & Hasil \\
\hline Kapang & koloni/g & $<1,0 \times 10^{1}$ \\
\hline
\end{tabular}

Hasil perhitungan bakteri Tabel 1 menunjukkan bahwa mikroba kapang sebesar $<1,0 \times 10^{1} \mathrm{koloni} / \mathrm{g}$. Ini menunjukkan bahwa ekstrak kulit jeruk nipis (Citrus aurantifolia) memiliki potensi untuk dijadikan sebagai agen antibakteri. Semakin kecil hasil pengukuran yang diperoleh maka semakin kuat senyawa bioaktif dalam menghambat pertumbuhan bakteri. Inovasi produk antiseptik hand sanitizer dengan menggunakan ekstrak tanaman yang ada di alam yang mengandung sifat antibakteri yang terkandung dalam jeruk nipis

\section{Kesimpulan}

Konsentrasi karbopol mempengaruhi sifat fisik dan stabilitas fisik gel. Peningkatan konsentrasi Karbopol meningkatkan viskositas sediaan. Berdasarkan hasil penelitian yang dilakukan, maka dapat disimpulkan bahwa jeruk nipis (Citrus aurantifolia) memiliki potensi untuk menghambat pertumbuhan kapang $<1,0 \times 10^{1} \mathrm{koloni} / \mathrm{g}$. 


\section{Ucapan Terima Kasih}

Penulis mengucapkan terima kasih kepada Kemenristek Dikti atas hibah Penelitian Dosen Pemula (PDP) dan Universitas Teknologi Sulawesi yang telah membantu sehingga penelitian ini dapat terlaksana dan tulisan ini dapat diterbitkan.

\section{Daftar Pustaka}

Hapsari, I., Rosyadi A. Wahyuningrum R. 2014. Optimasi Kombinasi Minyak Atsiri Bunga Kenanga dengan Herba Kemangi dalam Gel sebagai Repelan Nyamuk Aedes aegypti dengan Metode Simplex Lattice Design. Fakultas Farmasi, Universitas Muhammadiyah Purwokerto. Skripsi.

Kuncari, E. S., Iskandarsyah, \& Praptiwi. (2014). Evaluasi, Uji Stabilitas Fisik dan Sineresis Sediaan Gel Yang Mengandung Minoksidil, Apigenin dan Perasan Herba Seledri (apium graveolens L.). Bul. Penelit. Kesehat, 42(4), 213-222. https://media.neliti.com/media/publications/20088-ID-evaluasi-ujistabilitas-fisik-dan-sineresis-sediaan-gel-yang-mengandung-minoksid.pdf

Sari, R., \& Isadiartuti, D. (2006). Studi Efektivitas Sediaan Gel Antiseptik Tangan Ekstrak Daun Sirih (Piper betle Linn.). Majalah Farmasi Indonesia, 17(4), 163-169. http://ilib.ugm.ac.id/jurnal/detail.php?dataId=10171

Suparsa, N., Maharani, A. A. P., \& Dewi, N. K. S. A. (2020). Edukasi Cara Pembuatan Handsanitizer Dari Lidah Buaya. Prosiding Seminar Regional Pengabdian Kepada Masyarakat Unmas Denpasar Di Masa Pandemi Covid-19, 245-251. https://e-journal.unmas.ac.id/index.php/ProsidingCovid19/article/view/1986

Wijaya, J. I. (2013). Formulasi Sediaan Gel Hand Sanitizer Dengan Bahan Aktif Triklosan 1,5\% dan $2 \%$. Jurnal Ilmiah Mahasiswa Uiversitas Surabaya, 2(1), 1-14. 